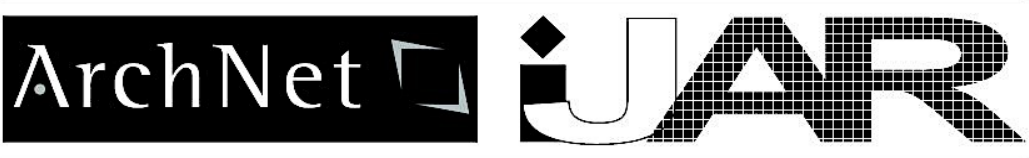

Archnet-IJAR: International Journal of Architectural Research www.archnet-ijar.net/ -- https://archnet.org/collections/34

\title{
THE PRACTICE OF CITY PLANNING AND DESIGN IN THE GULF REGION: THE CASE OF ABU DHABI, DOHA AND MANAMA
}

DOI: http://dx.doi.org/10.26687/archnet-ijar.v12i2.1460

\author{
Asmaa Saleh AL-Mohannadi, Raffaello Furlan
}

\section{Keywords}

Globalization; rapid urbanization process; urban design; development vision; Arabian gulf region; capitals; megaprojects.

ArchNet-IJAR is indexed and listed in several databases, including:

- Avery Index to Architectural Periodicals

- EBSCO-Current Abstracts-Art and Architecture

- CNKI: China National Knowledge Infrastructure

- DOAJ: Directory of Open Access Journals

- Pro-Quest

- Scopus-Elsevier

- Web of Science

\section{Abstract}

This research study explores the Arabian Gulf region's practice of city planning and design in response to the active forces of globalization. The focused scope of analysis is justified by the commonalities that unite the Arabian Gulf region; among them is the active response to globalization and the rapid urbanization process. Following the coverage of the regional context, an investigation of the city planning and design is presented in the study as a case study approach. Three coastal Arabian Gulf capitals -Abu Dhabi, Doha and Manama- are selected as primary units of analysis, investigating their urban evolution, the recent planning practice and urban development vision. The aim of the research study is to establish a theoretical connection between Gulf cities relying on their commonalities. The hypothesis assumes globalization to create a common urban planning practice based on (A) geopolitical facts, $(B)$ historical evolution of urbanism and (C) the recent urban development trends that shape Gulf capital cities. The findings reveal that the urban practice in the Gulf region has been constantly altered in response to global challenges. New trends of megaprojects and international planning are dominating the urban development and growth of Gulf capital cities, where the knowledge of international expertise is flowing into the local planning practice. Therefore, the future of the urbanism is expected to focus on comprehensiveness, master planning in the national scale, as well as establishing a regional interconnection as a strategic development vision unifying the whole Arabian Gulf region.

\section{A. Saleh AL-Mohannadi, R. Furlan*}

Asmaa Saleh AL-Mohannadi

Masters Candidate, College of Engineering, Department of Architecture and Urban Planning, Qatar University. Raffaello Furlan, PhD.

Assistant Professor, College of Engineering, Department of Architecture and Urban Planning, Qatar University. 


\section{INTRODUCTION}

In the context of globalization, which attempts to define the rapid process of international integration in the various scales, the evolution of the city and regional planning is becoming a major contemporary challenge. The theory of "global city" establishes the basis for recent trends of urbanization and a justification for the rapid city planning process focusing on connectivity and attracting global flows (Lim, 2005). However, the historical genesis of planning, which is highly associated with socio-cultural traits of a definite society and the geographical context of the region, resists the recent global trends and provides a counter process of urban development that is more local-oriented, inward and responsive to the indigenous formation of cities (Furlan, Eissa, Awwad, \& Awwaad, 2015; Furlan \& Faggion, 2017; Furlan, N.Eiraibe, \& AL-Malki, 2015; Furlan \& Sipe, 2017).

This research study focuses on the evolving realities of urbanism and its practices in response to the active forces of globalization covering the context of the Arabian Gulf region. The focused scope of analysis is justified by the commonalities that unite the Arabian Gulf region; among them is the active response to globalization and the rapid urbanization process (Furlan, 2015; Furlan \& Alattar, 2017b; Furlan \& Faggion, 2015a). Following the coverage of the regional context, a thorough investigation of city planning is presented in the research study as a case study approach. Three coastal Arabian Gulf capitals are selected as primary units of analysis, focusing on their urban evolution and examining their recent urban development practices.

The aim of this research study is to establish a theoretical connection between Gulf cities relying on their commonalities with a hypothesis that assumes globalization to create a common urban planning practice (Furlan, 2016; Furlan \& Alattar, 2017a; Furlan \& Wadi, 2017). The hypothesis is justified by the coastal locations of the selected cities, historical evolution of urbanism, and the recent urban development visions that shape the Gulf city. The main questions of the research study are the following: how has globalization as a comprehensive process altered and changed the urban planning and design practices of the Gulf region with reference to its historical evolution? What are the recent global trends of urban planning practiced by the Gulf cities? In addition, is there a way to perceive the Gulf region as a unit in terms of urbanism and planning practice?

Establishing a common ground of urbanism and city design would support the unitary approach of the Gulf region to facilitate their collaboration and to further utilize the powers imbedded within their intergovernmental political union, the Gulf Cooperation Council (GCC). Thus, the practices of urban planning and design should be challenged by a long-term system that ensures regional collaboration, public participation and the effective integration of the private sector as most of the recent planning practices in the Gulf region are on the hands of the government.

\section{LITERATURE REVIEW}

The concept of globalization, which is commonly comprehended as an economic process of market liberalization, has various and multi-faceted definitions based on the specific approach that fits the targeted topic of research. Hence, globalization could be redefined under any theory, based on the scope the researcher aims to justify, while maintaining the essence of the definition as a trend of openness, flows and global connections. A definition of globalization that would be appropriate in the context of urban planning is explained by Grill- 
Chin Lim as "an integration of the world economy, removing trade barriers and allowing freedom of interaction" (Lim, 2005). The author further examines the relationship between globalization and urban spatial development based on arguments for and against globalization, global problems and trends, as well as historical observation on urban development. Lim's major argument is that "globalization trends lead to resource allocation consequences and that these in turn result in urban impacts" (Richardson \& Bae, 2005).

Considering the selected case study of the Arabian Gulf region and its coastal cities, a review of the literature on this specific regional context highlights the scarcity of references due to the short timeline of historical evolution in the Gulf region compared to the other worldwide regional contexts (Furlan \& Almohannadi, 2016; Furlan \& Faggion, 2017; Furlan \& Petruccioli, 2016; Furlan \& Sipe, 2017; Furlan, Zaina, \& Zaina, 2016). One of the most remarkable references is an interpretative-historical book titled "Seafaring in the Arabian Gulf and Oman: People of the Dhow," (Agius, 2005), which presents a sequential historical evolution of Gulf cities. Agius highly depends on primary sources such as archival materials, interviews with local personalities who lived in coastal Gulf cities, in addition to his site-visits to the coastal Gulf capitals at different time intervals since the 1990's.

Referring to the theoretical framework of this research study, "Readings in Planning Theory" (Campbell \& Fainstein, 2012) also provides an applicable basis with reference to planning in a globalized world. In the article "Re-Examining the International Diffusion of Planning," the question explores how planning ideas adapt as they move across borders, attempting to examine the effect of globalization and global flows on the practice of urban planning (Ward, 2012). Ward develops a useful typology of six variants defining the models of planning diffusion with a distinctive description of each model. The typology is developed as a general framework to examine any region in the world with reference to its planning diffusional type, analysing the indigenous role, external role, level of diffusion and the key actors in the planning practice.

However, a recent study on planning for urban megaprojects in the Gulf suggests that instead of diffusion being the determinant of the planning practice, it is the "knowledge transfer process" adopted by international consultancy firms that becomes the recent trend of planning in the era of globalization (Aoun \& Teller, 2016). The study also contributes to the analysis of the current evolution of urban planning practices in the Gulf region, which is assumingly characterized by the emergence of megaprojects and international consultancy firms (Furlan \& El-Ekhteyar, 2016; Furlan \& Saeed, 2017; Remali, Salama, Wiedmann, \& Ibrahim, 2016; Salama \& Wiedman, 2013 a and b; Wiedmann, Salama, \& Mirincheva, 2014).

The case studies of coastal Gulf capitals are analyzed individually with a common framework of analysis targeting each cities' historical urban evolution, phased progress before and after the wealth of oil and the trends of planning practice during the current globalization era. The book titled "The Evolving Arab City" establishes a unifying category assuming the selected coastal Gulf capitals as emerging cities compared to the other struggling Arab cities (Elsheshtawy, 2008).

The urban evolution of Abu Dhabi in the United Arab Emirates is the most cited case with primary sources of films, records, and archival materials. An archival film titled "Farewell Arabia" (Farewell Arabia, 1968) presents intensively the political and socio-cultural circumstances that shape Abu Dhabi's urban evolution during its pre-oil phase. Other secondary references include journal papers and books that evaluate the recent planning 
practice in the Gulf cities with a great emphasis given to the planning governance as the gear for urban growth.

The literature review indicates that coastal Gulf cities are unified in many prospects including their recent urban planning practices and development visions. Sustainability and sustainable urbanism are becoming the counter trends facing the negative effects of globalization in the planning arena including the overdependence on international planning contracts, megaprojects, star-architecture and rapid scale development (Furlan, Almohannadi, Zaina, \& Zaina, 2015; Furlan \& Mogra, 2017; Furlan \& Shurbaji, 2017). Each of the three Gulf capitals are pursuing distinction, yet visions of development are common and require a further collaborative framework utilizing the resources available to the GCC.

Another important remark is the actual utilization of the term "urban planning", which has theoretical limitations when analysing the regional context of the GCC. Instead, most of the studies concerned with the GCC are focusing on the vision of cities; their tendency to grow as global hubs under a continuous pressure to offer economic growth beyond the physical and functional practices of urban planning. Thus, Gulf cities are envisioned as global hubs reshaped by mega scale projects and a rapid construction boom.

Considering the pure physical and organizational aspects of urban planning, it is still challenging in the context of the GCC as most of the cities are still rooted in automobilebased urbanism. The car has generated problems of urban efficiency, contributing to traffic congestion, pollution, fragmentation of urban fabric and other environmental and social challenges. In the context of the GCC, the over-dependency on the automobile is justified by the lack of alternative modes of transportation that could support the need to connect fragmented urban districts and provide efficient solution to urban sprawl (Salama, 2011). Such urban challenges are delaying the sustainable urban development of Gulf cities and are critically considered as national priorities that require serious administrative intervention as well as regional collaboration.

Also, it is of cardinal relevance to stress that most of the literature on the Gulf region is concerned with historical, political or security studies aligning with the field of military or political science, proving the priorities of research in this region are targeting national security and political stability. However, as the higher authorities in the Gulf region are envisioning a sustainable future by focusing on internal urban development, recent publications on urban planning are found to be either sponsored by governments or supported by local research institutes, such as the book titled "Al-Manakh 2: Gulf Cont'd" (Reisz \& Koolhaas, 2010), which is the work of a private international office, published under the exclusive sponsorship of the Abu Dhabi UPC and incorporates a series of articles written by national and foreign professionals. Another publication is "History of Land use \& Development of Bahrain" (AlNabi, 2012) that is sponsored by Bahrain's Information Affairs Authority. These publications highlight the need to adopt an interdisciplinary approach of urban planning as a theoretically collaborative discipline, supporting the need for further multi-disciplinary collaboration on the practical field.

\section{THE RESEARCH DESIGN}

In the process of exploring the effects of globalization on the urban planning practices, the variables of investigation are defined by $(A)$ the contextual, $(B)$ the evolutionary and $(C)$ the current planning variables. For the contextual variable, the study is targeting the context of 
the Arabian Gulf with the specific selection of the coastal national capital cities of Abu Dhabi, Doha and Manama. This context has its own response to the forces of globalization as a process primarily due to the region's economic transformation after the discovery of oil (Khalaf, 2006; Salama et a., 2016).

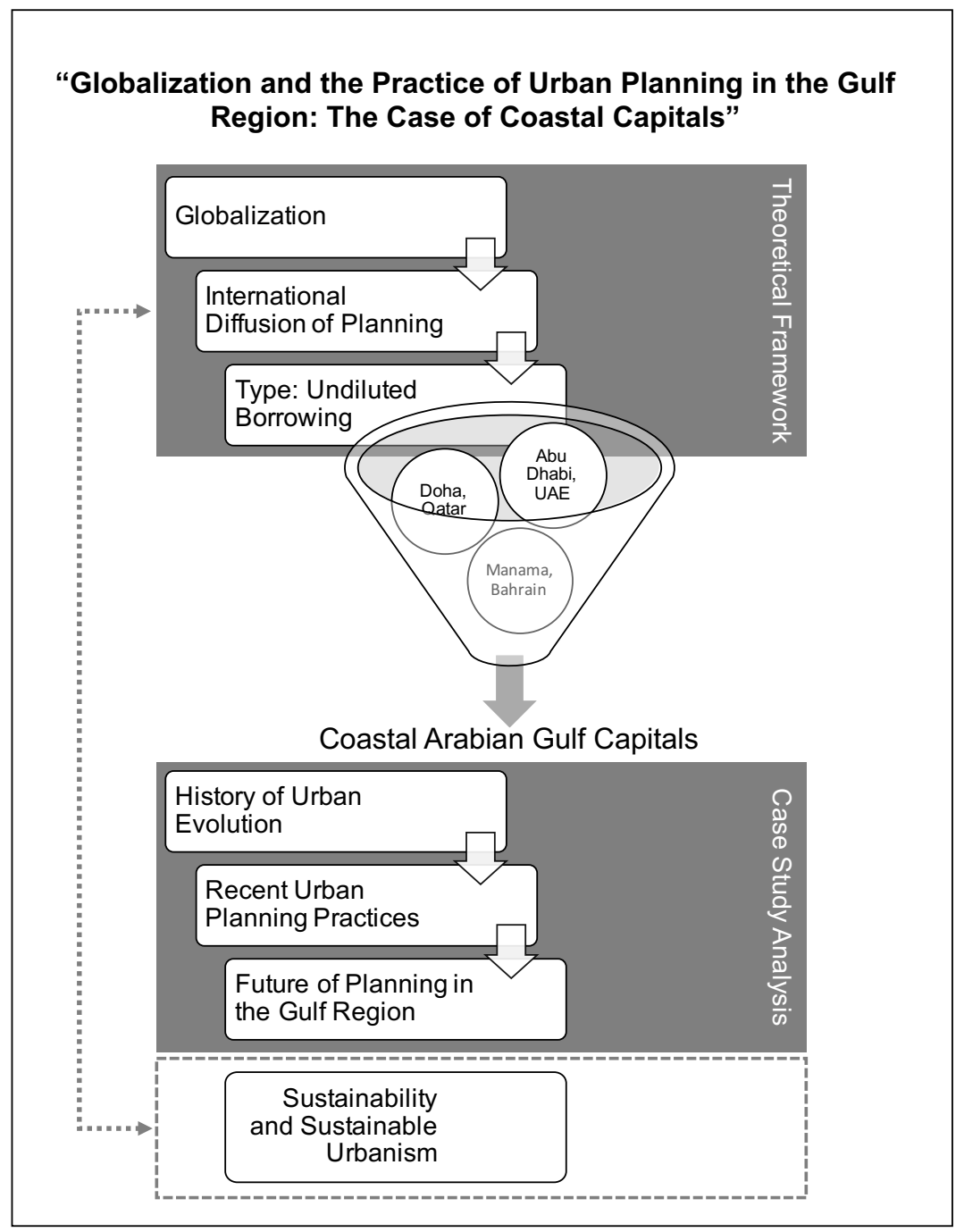

Figure 1: Methodological Framework (Source: Authors).

The evolution of urban planning in the Gulf region is a major variable of interest as it provides a logical sequence that is framed by a progressive timeline. Major urban shifts reshape the urban planning practice resulting from the oil wealth in various scales and different phases. Urban planning itself was the Gulf's first response to modernity since the foundation of infrastructure and the creation of a modern state are highly dependent on the planning practice (Furlan, 2015, 2016; Furlan, Almohannadi, et al., 2015; Furlan \& Faggion, 2015a, 2015b; Furlan, Nafi, \& Alattar, 2015; Furlan et al., 2016). It also directs attention to the willingness of the political authorities in the Gulf's selected cities to capitalize the sudden wealth internally, which continues to be a major characteristic of the current planning practice. However, the current planning practice is characterized by population growth, the 
emergence of megaprojects, as well as the dependence on international planning firms to regulate the planning practice within the emerging Gulf cities (Aoun \& Teller, 2016).

The research design is based on the case study analysis as it traces the urban evolution of three selected cities then establishes conclusions regarding their commonalities and recent urban planning practices (Barnes, 1959; Creswell, 1994; Denzin \& Lincoln, 2005; Marshall \& Rossman, 2006; Newman, 2007; Ragin, 1994; Zeisel, 1984). The hypothesis is assuming the cities of the Gulf to have similar trends in the planning practice especially during the era of globalization (Figure 1).

\section{Data Presentation and Analysis}

This section discusses the general profile of the investigated region considering the attributes of history, urbanization, climate, demography and socio-political profiles. In addition, the typology of the planning practice in the region is identified based on the theoretical framework of international diffusion of planning. Then, a sample of the three capital cities in the Gulf region is selected as the unit of analysis based on coastal locations. The capital cities of Abu Dhabi in the United Arab Emirates, Doha in the State of Qatar, and Manama in the Kingdom of Bahrain have been selected for analysis in terms of their historical urban evolution, recent planning practices and visionary urban response to globalization.

\section{I-Profile of the Studied Region: The Arabian Gulf Region}

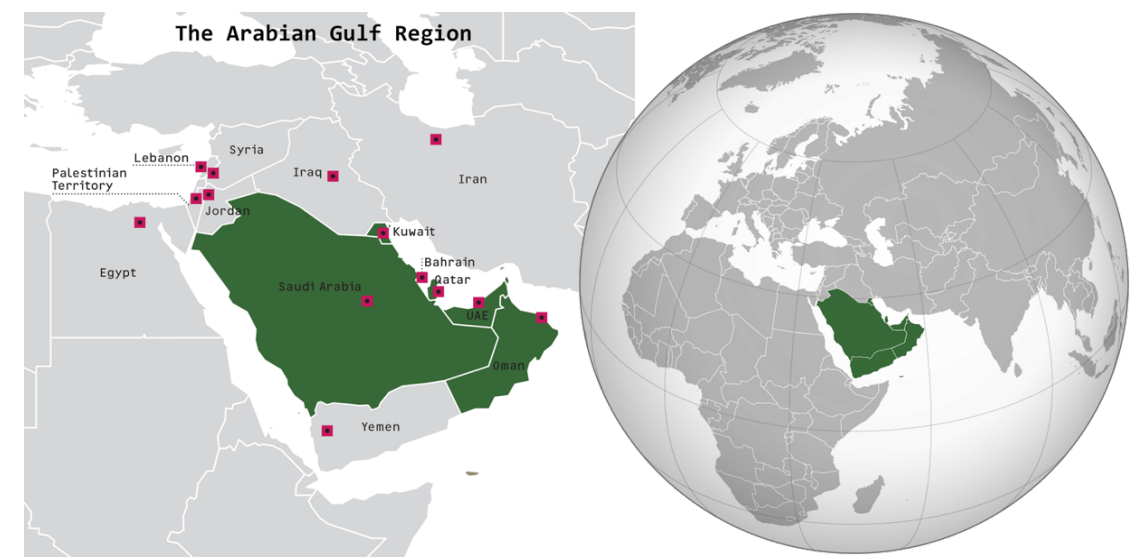

Figure 2: The Arabian Gulf Region (Source: Pahl-Weber, Seelig, Ohlenburg, \& Bergmann, 2013).

The Arabian Gulf region is a vast area extending over the coastline of the Arabian Gulf sea including the six countries of the Kingdom of Saudi Arabia, Sultanate of Oman, United Arab Emirates, State of Qatar, Kingdom of Bahrain and State of Kuwait. These countries make up the union of the Gulf Cooperation Council, the GCC, and are bordering the inland sea from the southwest, while the Islamic Republic of Iran is bordering the northeast coastline. The naming of the region itself has been a center of dispute between the Arabs and Iranians since the 1980s, due to the region's political instability and the series of wars such as the Iraqi-Iranian war and the second Gulf war of Kuwait (AI Nahyan, 2000). 


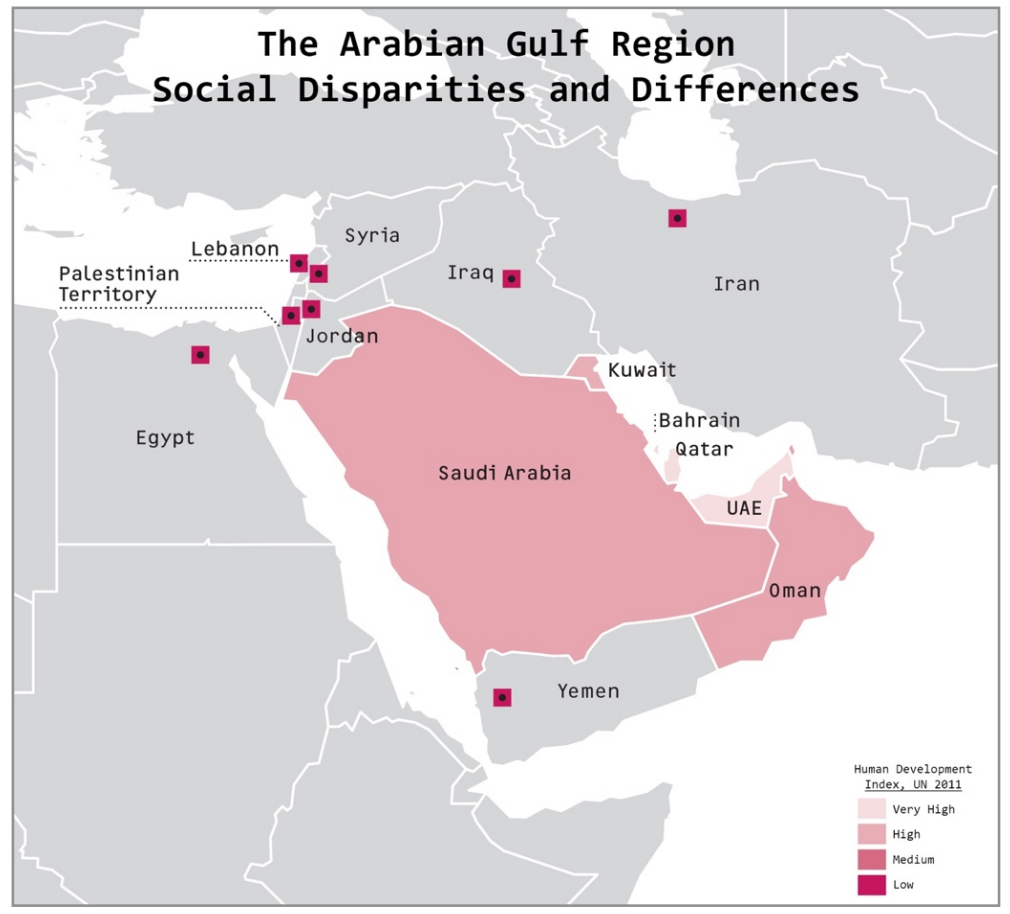

Figure 3: Urbanization in the Gulf Region (Source: Pahl-Weber, Seelig, Ohlenburg, \& Bergmann, 2013).

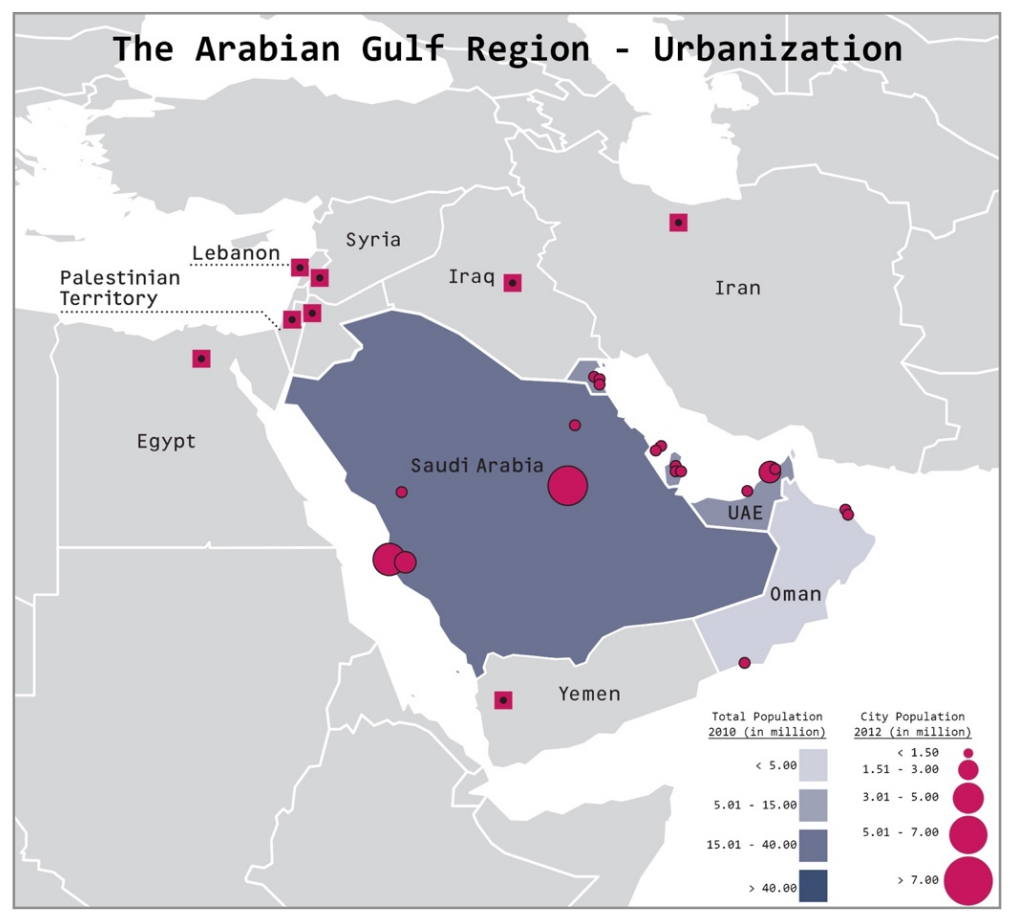

Figure 4: Social Disparities and Differences (Source: PahlWeber, Seelig, Ohlenburg, \& Bergmann, 2013). 
In 1970s, the entire population of the Arabian Gulf region was 7.8 million residents of Arab and nomadic origins. Most of the population were active in trade and hunting, while those who resided on the coastlines of the Gulf were engaged in sea activities such as sea-trading, pearling and fishing (Ramadan, 2015). Today, the Arabian Gulf region is experiencing a rapid population growth with 40 million inhabitants living in urban areas and participating effectively in the creation of their global cities. According to the United Nations Statistics Division, causes of rapid population growth are international immigration, migration due to national conflicts and high human development index especially in coastal gulf countries of UAE, Qatar and Bahrain (UN-Habitat, 2012).

Considering the wider region of Middle East and North Africa, countries within the Gulf region are viewed as relatively small oil rich nations with high income per capita allowing for better human conditions, less disparities and differences in the socio-economic aspects and higher investment on citizen's education and health care.

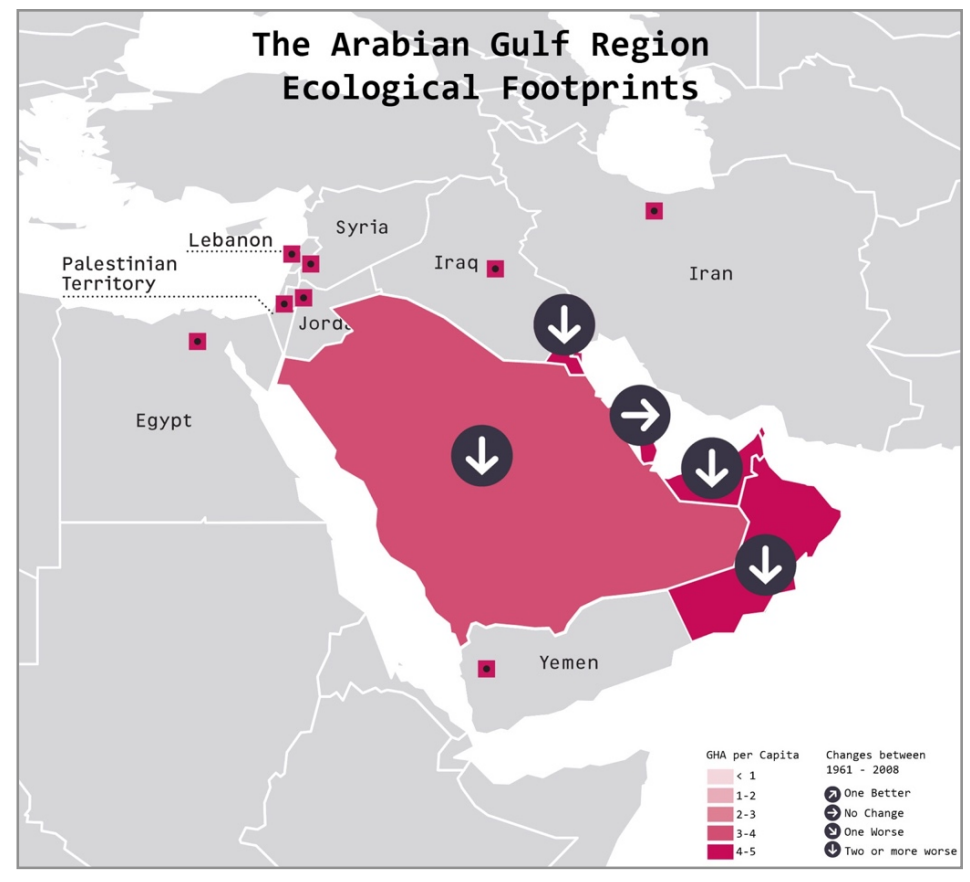

Figure 5: Ecological footprints of the Arabian Gulf Region (Source: Pahl-Weber, Seelig, Ohlenburg, \& Bergmann, 2013).

The Arabian Gulf region is characterized by its arid climate, desert landscape and hot temperatures. These geographical facts remain constant over time and inspired the rural population of the region to adopt a wide range of urban strategies to survive the harsh climate. The sea was the source of life, income, activity and connection to the external world. Thus, urbanism in the Gulf is initiated along the coastline and developed into the hinterlands creating cities of an active coastal character with various activities and job opportunities for the indigenous population (Agius, 2005). 


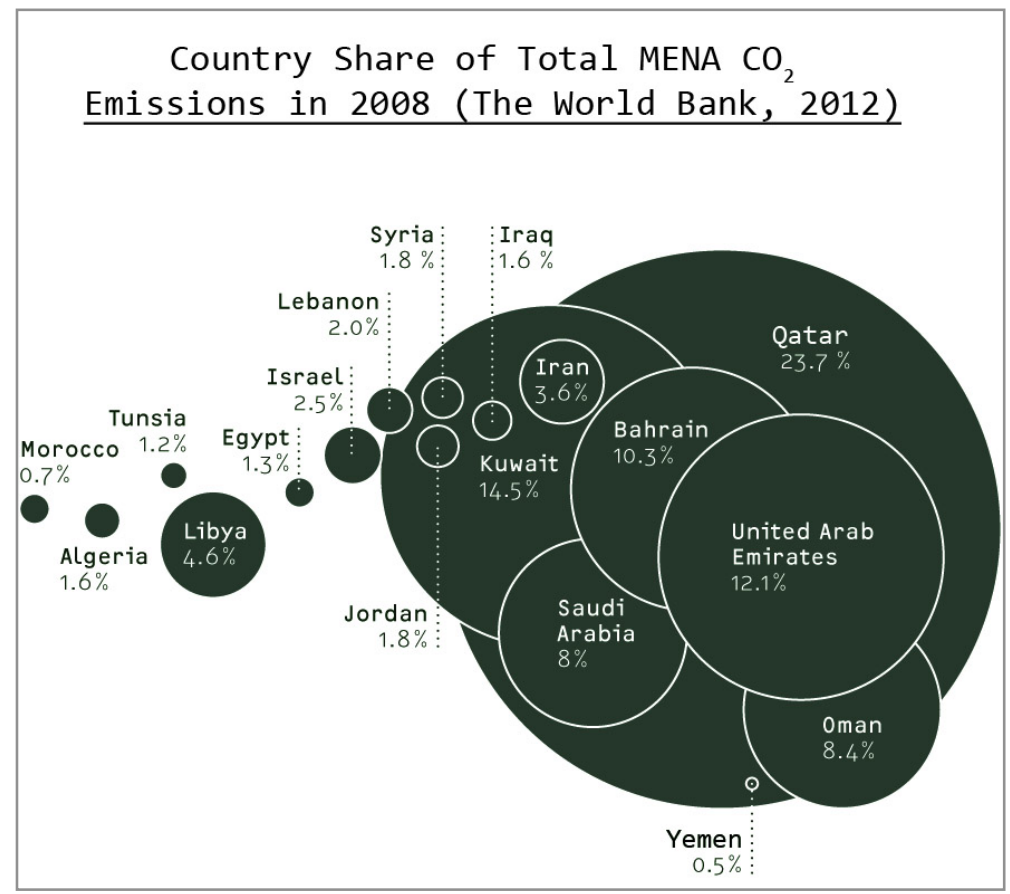

Figure 6: Country share of CO2 Emission in MENA (Source: PahlWeber, Seelig, Ohlenburg, \& Bergmann, 2013).

Today, the Gulf region depends highly on the oil and gas industries as the modern wealth generators that count for the transformation of the entire region into a globalized hub. However, the negative consequences are recently appearing on surface as high energy consumption, environmental problems and high carbon dioxide emissions (UN-Habitat, 2012). Urbanization of the Gulf region, therefore, is challenged by the negative consequences of globalization including the challenge of urban infrastructure, housing development, energy demand and quality, coastal degradation as well as governance challenges. Not only the indirect effects of globalization, but also direct global crises are upsetting the role of urban planning on sustainable growth of the Gulf cities (Reisz \& Koolhaas, 2010).

\section{II-International Diffusion of Planning: Undiluted Borrowing}

Theory of Planning is "an act of intellectual vanguard, pushing the professional field to rethink its outdated practices and the assumptions that underlie them" (Campbell \& Fainstein, 2012). It is highly responsive to the up-to-date urban phenomena such as sprawl, globalization and rapid urban growth. In addition, planning theory is characterized by its evolution and adaptation to a certain context.

In the globalized world of today in which planning theory is seen as an idea that could flow and move across societies, it is the local practice that manages the global flow of ideas within an inclusive perspective allowing cities and regions to evolve in a balanced way. Global theories of planning are aiding this progressive development of cities. According to the theory of planning diffusion, "planning ideas are not always imported unadulterated: they 
are often filtered, diluted, altered, or subverted. Diffusion frequently leads to innovation in which local ideas; institutions, and capacities are incorporated" (Campbell \& Fainstein, 2012).

International diffusion of planning is classified into a set of types based on the attributes of globalization; borrowing and imposition or import and export. Referring to Steven V. Ward, the developer of the typology of international diffusion of planning, "the essential basis of the typology is that of context, specifically the power relationship between the countries originating and receiving planning models, is always of critical importance" (Ward, 2012). The typology includes six variants categorizing the level of diffusion based on the indigenous role in planning, external role, mechanism or practice of planning, key actors as well as the potential of the diffusional type for distinctiveness. Table (1) below summarizes the typology of diffusion.

\begin{tabular}{|c|c|c|c|c|c|c|c|}
\hline Type & $\begin{array}{l}\text { Indigenous } \\
\text { Role }\end{array}$ & $\begin{array}{c}\text { External } \\
\text { Role }\end{array}$ & $\begin{array}{c}\text { Typical } \\
\text { Mechanisms }\end{array}$ & $\begin{array}{l}\text { Level of } \\
\text { Diffusion }\end{array}$ & $\begin{array}{c}\text { Key } \\
\text { Actors }\end{array}$ & $\begin{array}{c}\text { Potential for } \\
\text { Distinctiveness }\end{array}$ & $\begin{array}{c}\text { Characteristic } \\
\text { Examples }\end{array}$ \\
\hline $\begin{array}{l}\text { Synthetic } \\
\text { borrowing }\end{array}$ & Very high & Very low & $\begin{array}{l}\text { Indigenous } \\
\text { planning } \\
\text { movements } \\
\text { plus wide } \\
\text { external } \\
\text { contacts }\end{array}$ & $\begin{array}{l}\text { Theory } \\
\text { and } \\
\text { Practice }\end{array}$ & Indigenous & Very high & $\begin{array}{l}\text { Major } \\
\text { countries of } \\
\text { Western } \\
\text { Europe and } \\
\text { USA }\end{array}$ \\
\hline $\begin{array}{l}\text { Selective } \\
\text { borrowing }\end{array}$ & High & Low & $\begin{array}{l}\text { External } \\
\text { contact with } \\
\text { innovative } \\
\text { planning } \\
\text { traditions }\end{array}$ & $\begin{array}{l}\text { Practice } \\
\text { and } \\
\text { some } \\
\text { theory }\end{array}$ & Indigenous & High & $\begin{array}{l}\text { Smaller } \\
\text { countries of } \\
\text { Western } \\
\text { Europe }\end{array}$ \\
\hline $\begin{array}{l}\text { Undiluted } \\
\text { borrowing }\end{array}$ & Medium & Medium & $\begin{array}{l}\text { Indigenous } \\
\text { deference to } \\
\text { innovative } \\
\text { external } \\
\text { planning } \\
\text { traditions }\end{array}$ & $\begin{array}{l}\text { Practice } \\
\text { with little } \\
\text { or no } \\
\text { theory }\end{array}$ & $\begin{array}{l}\text { External } \\
\text { with some } \\
\text { indigenous }\end{array}$ & Fairly Low & $\begin{array}{l}\text { Dominions of } \\
\text { British Empire, } \\
\text { Japan, and } \\
\text { some } \\
\text { European } \\
\text { examples }\end{array}$ \\
\hline $\begin{array}{l}\text { Negotiated } \\
\text { imposition }\end{array}$ & Low & High & $\begin{array}{l}\text { Dependence } \\
\text { on external } \\
\text { planning } \\
\text { tradition(s) }\end{array}$ & Practice & $\begin{array}{l}\text { External } \\
\text { with some } \\
\text { indigenous }\end{array}$ & Low & $\begin{array}{l}\text { Aid-dependent } \\
\text { countries (e.g. } \\
\text { Africa) }\end{array}$ \\
\hline $\begin{array}{l}\text { Contested } \\
\text { imposition }\end{array}$ & Very low & $\begin{array}{l}\text { Very } \\
\text { high }\end{array}$ & $\begin{array}{l}\text { High } \\
\text { dependence } \\
\text { on external } \\
\text { planning } \\
\text { tradition }\end{array}$ & Practice & External & Low & $\begin{array}{l}\text { "Enlightened" } \\
\text { colonial } \\
\text { planning }\end{array}$ \\
\hline $\begin{array}{l}\text { Authoritarian } \\
\text { imposition }\end{array}$ & None & Total & $\begin{array}{l}\text { Total } \\
\text { dependence } \\
\text { on one } \\
\text { external } \\
\text { planning } \\
\text { tradition }\end{array}$ & Practice & External & None & $\begin{array}{l}\text { Newly } \\
\text { subjected } \\
\text { territories }\end{array}$ \\
\hline
\end{tabular}

Figure 7: Steven V. Ward's Typology of Diffusion (Source: Ward, 2012). 
With reference to the Gulf region and its political history, the region was under the British informal domination during the 1820s until the 1970s right after the discovery of oil. In general, the Gulf region was freed from direct forms of colonization since the interest of the British empire in the region was purely logistic and economic interests (Onley, 2005). Fitting this historical context, the planning theory type that would best resemble the practice in the Gulf region is of an undiluted borrowing type. According to Ward's explanation of the diffusional type, "it reflects a rather underdeveloped indigenous planning movement and, quite often, a high reliance on foreign planners to supply leadership" (Ward, 2012).

Thus, the twentieth century planning practice in the Gulf region came through the prism of the British experience, as the region's low-populated and poorly urbanized sheikhdoms were self-governed and lacked professional planning resources. The British informal empire in the Gulf, which was peaceful and collaborative rather than forced and colonial, supports the dependence on imperial planning models and eases the process of borrowing. During the initial phase of modernization in most of the Gulf region, beginning right after the discovery of oil in the 1960s, British administrative planning was adopted in the capital cities of the Gulf states (Elsheshtawy, 2008). The memory of Shaikh Zayed bin Sultan Al-Nahyan, the modern founder of the United Arab Emirates and ruler of its capital Abu Dhabi, who was personally involved in the initial meetings with the first British planning professionals to work in the country, is still perceived as a remarkable scene of the urban planning history in the Gulf (Farwell Arabia, 1968).

Later on, with the inflation of oil prices and the presence of the American powers in the area due to the global and regional wars, American and western influences became dominant and replaced, or in some cases coexisted with what the British planning system created on ground.

It is true that the diffusional typology depends on a historical context, as Ward argues, but the recent global market forces allow borrowing to be faster and comprehensive in its approach, process and choices (Ward, 2012). A clear justification for this argument is the high presence of international firms that are specialized in planning, consultancy and engineering dominating the urban planning domain not only in the Gulf region, which is still considered a developing region, but also worldwide. Such firms adopt a knowledge-transfer process rather than the conventional diffusional theory. In addition, diffusion has limitations as it fails to describe: "how policies or practices were altered during the adaptation process" (Aoun \& Teller, 2016).

\section{CASE STUDY SELECTION: THE COASTAL ARABIAN GULF CAPITAL CITIES}

The case study analysis is based on three major components including the general historical evolution of the selected city cases, recent urban planning practices, and a forecast of the future of urban planning and urbanism considering the theory of sustainability and sustainable urbanism.

As a common approach, "development in one city affected other Gulf cities in subtle as well as obvious ways" (Reisz \& Koolhaas, 2010). Thus, the urban evolution of the Gulf city is exponentially phased. Four predefined phases of the urban evolution are identifying the historical urbanism of the Gulf city, excluding the phases of old civilization and pearl industry due to the focus of the research study on modern history. The four phases are the pre-oil 
phase (1950-1960); modernization period (1960-1970); oil-price inflation phase (1970-1980); and the Globalization era (1980-present).

During the pre-oil phase, which is characterized by the autonomous planning practice of the indigenous population, the most important urban features of Gulf cities are their reliance on the sea activities as the source of income and the existence of old urban cores within coastally-oriented cities (Al Maimani et al., 2014). The main building establishments were mere housing facilities of a courtyard typology built with simple local techniques and materials. While the modernization period's most urban features include the establishment of urban cities and modern infrastructure aided by the British administration.

The oil-price inflation phase was marked by the massive urbanization in the Gulf capitals seen as the centers of political authority where most of the state establishments such as road networks and governmental offices were planned and built. Finally, the recent globalization era is characterized by the comprehensiveness of the planning practice and the effective governance of the planning process (Khalaf, 2006).

The final globalization phase could be further divided into two stages. The first is the domination of initial free trade zones and offshore banking between the 1980s and 1990s, while the second stage is characterized by the massive construction boom, which is marked by the rethought development visions of the Gulf cities in an attempt to maintain growth rates and challenge global crises as the negative consequence of the process.

Recently, the conflict that arose in the regional urban context is concerned with the ambitious development visions of creating global hub cities against growth-dependent cities struggling to keep a steady economic growth. Another urging conflict is the need to consider a sustainable design practice through responsive application of urbanism to the local requirements, as the recent construction industry is adjusting to efficient development rather than reinventing sustainable design practices.

\section{I-Abu Dhabi}

Globalization has certainly altered and changed the planning practice of Abu Dhabi, the capital city of the United Arab Emirates, which has a rich urban history that begins in the 1960s and grows exponentially until the recent era (Elsheshtawy, 2008).

One of the most important alterations of globalization on the planning practice of Abu Dhabi is targeting the planning governance. The openness to the global market transforms the planning governance in Abu Dhabi as it pushes the conservative political authorities to seek partial liberalization. An application for this alteration on the planning practice is seen through the implementation of the Abu Dhabi Ownership Law of 2005, which "opened the door to greater, albeit still limited, foreign investment" (Khirfan \& Jaffer, 2013). The law allows international planning advisory and consultation to supervise most of the planning projects in the capital city. The result of this approach creates an over-dependence on expatriate technical expertise and low waged migrant workers (Murray, 2013). It also establishes a new typology of projects characterized by its large-scale, global themes and westernized marketing styles. Such trends are entirely managed by foreign developers and consultants where the "Urban Planning Council has little or non-existing power in guiding the growth engine" (Ponzini, 2011). 
Another important change in the urban planning practice brought by globalization is the shift of the planning direction towards sustainability and sustainable urbanism (Khirfan \& Jaffer, 2013). Abu Dhabi is facing its own urban challenges through the global channels of knowledge-transfer supported by the active open-door policies. The city seeks an international adaptation of a sustainable model in urbanism, which is found to be embedded in the Canadian model of the city of Vancouver. Thus, "while Vancouver's model has been replicated with varying degrees of success in numerous locations, none was so intensive and well-funded a process as is currently underway in Abu Dhabi" (Khirfan \& Jaffer, 2013). Among the factors that supported the transfer of the Vancouver model into the context of Abu Dhabi is justified by the coastal location of the city, allowing for a better planning of open spaces for the public with the waterfront as a strategic urban core.

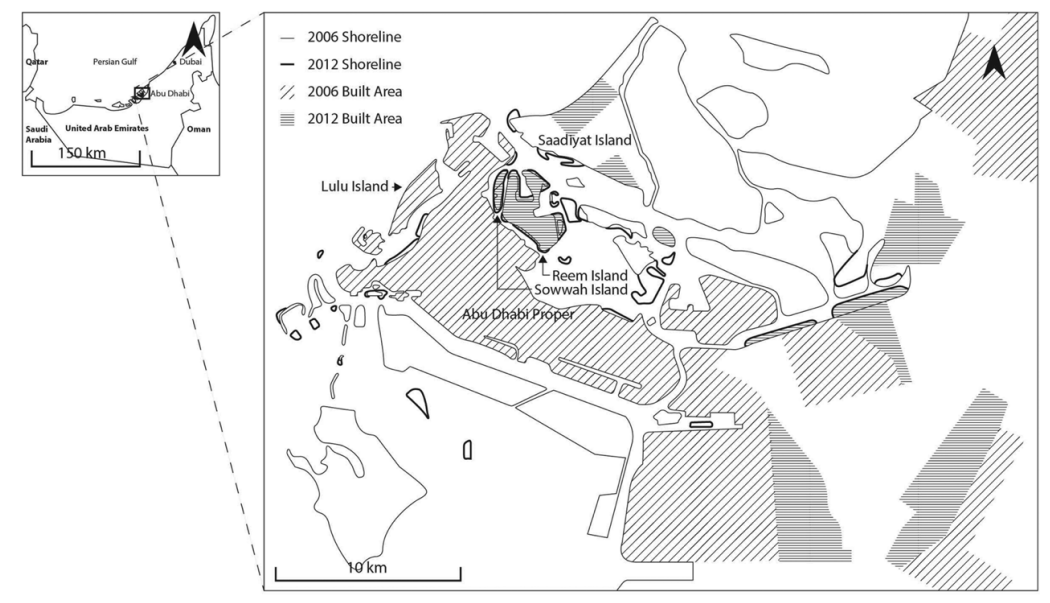

Figure 8: Expansion of the Built-Up Area in Abu Dhabi 2006 - 2012 (Source: Khirfan \& Jaffer, 2013).

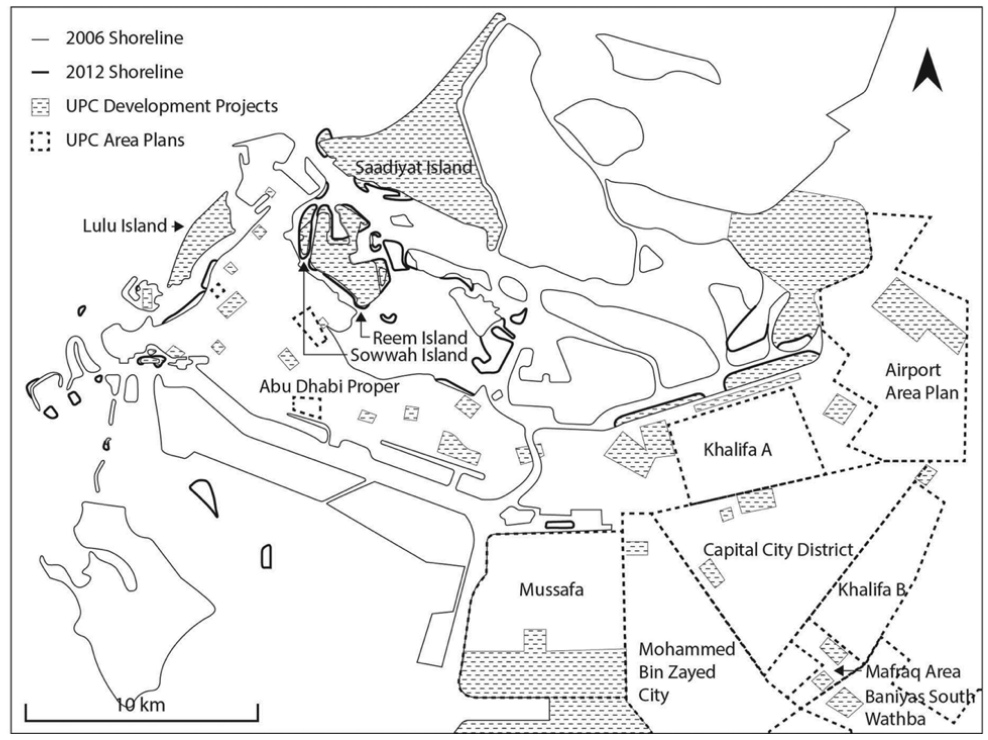

Figure 9: Location of Key UPC Development Project Sites (Source: Khirfan \& Jaffer, 2013). 


\section{II-Doha}

The global transformation of Abu Dhabi in the United Arab Emirates has been triggering a similar tendency for urban transformation within the regional context specifically in Doha, Qatar. This fact proves the strong connectivity and interrelations between the Gulf cities due to the previously explained profiles and the set of commonalities that unite the Gulf region.

A significant alternated trend of globalization on the planning practice of Doha is the trend of mega-projects (Mirincheva, Wiedmann, \& Salama, 2013; Salama et al., 2016), "which are usually launched by newly founded holdings, whose main shareholders are usually public institutions, because most unbuilt land is considered property of the state and thus under the authority of the rulers" (Wiedmann, Salama, \& Mirincheva, 2014). The trend of megaprojects supports the provision of modern urban facilities and attracts global flows into Doha through investment, transit, cultural and knowledge hubs. Examples for such megaprojects include the ongoing Qatar FIFA World Cup projects, infrastructure developments along with public and private real estate investments. However, the trend has created fragmentation in the urban structure and led to many negative impacts such as traffic congestion, environmental impacts and absence of public participation (Rizzo, 2014).

Responding to such emerging issues, a change in the urban planning practice of Doha has been shifting toward a collective planning framework. The aim is to avoid outdated planning practices as well as to limit the decentralization of decision-making. Recently, Doha has implemented a strategic plan for its urban development known as Qatar National Development Framework (QNDF), which targets the long-term management of growth, change, land use and development in Qatar. According to the urban analysis of QNDF, "livability, identity, and integration of existing and planned megaprojects are amongst the main policy priorities indicated in the plan, while density, mixed-use-development and hierarchy of centers are the main spatial concepts that should deliver the vision" (Rizzo, 2014).

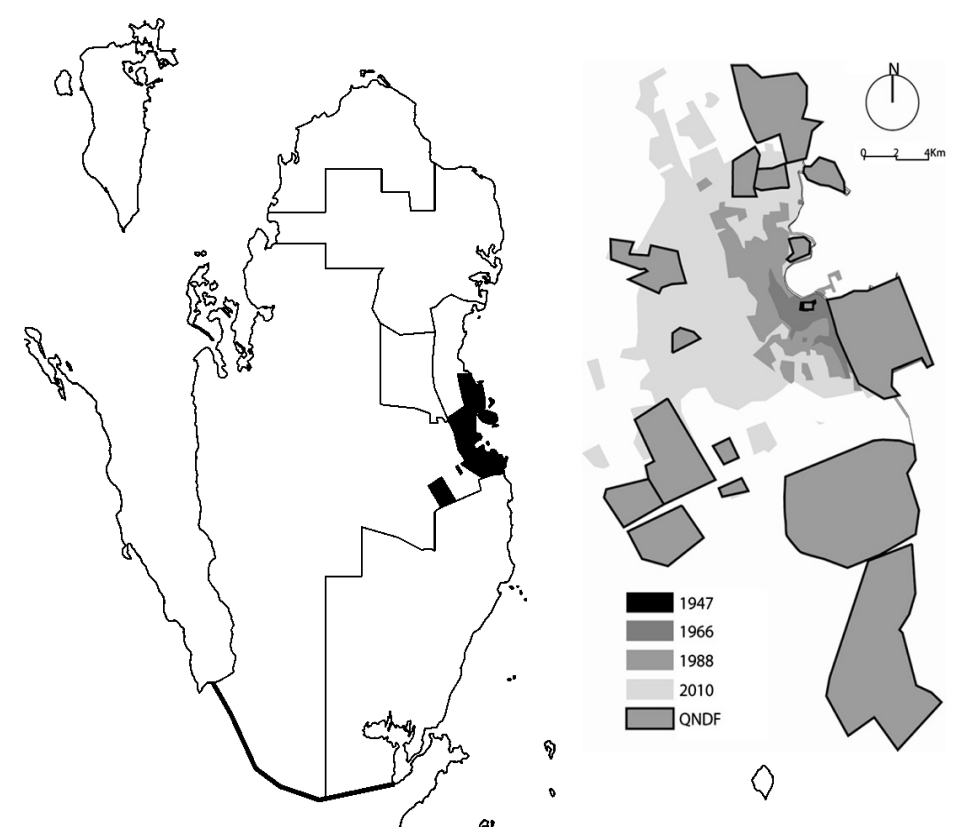

Figure 10: Urban Evolution of Doha along with QNDF megaprojects (Source: Rizzo, 2014). 


\section{III-Manama}

The city of Manama owes much its historical urban evolution to its coastal location on the northern coast of Bahrain overlooking the Gulf. It has been a strategic trade center, which continues to shape its sustainable development during the era of globalization as the city is intensively focusing on the sectors of tourism and finance. Considering the planning practice, Manama adopted modern town planning principles in the late 1960s through individual professional expertise appointed by the higher authorities of Bahrain (Al-Nabi, 2012).

Although early modern planning practice of Manama was highly considering the social cohesion of the city and its historical value, globalization has fiercely changed the urban morphology of Manama and distorted its historical core. Similar to Abu Dhabi and Doha, the trend of mega-projects overlooks the globalized urban scene of Manama, resulting on a conflicted urban fabric as "the vertical character and exhibitionist architecture contrast sharply with the low-profile skyline and local style of the old town" (Elsheshtawy, 2008). In order to limit the negative consequences of the global planning practice on Manama, two practical approaches are to be implemented. The first approach is to restrain the foreign actors to respond to local specificities such as climate, moral values and local cultures especially considering the local references of a genuine city like Manama. The second approach is to develop local human resources through knowledge-based networks, in order to utilize the national wealth internally (Hamouche, 2004).
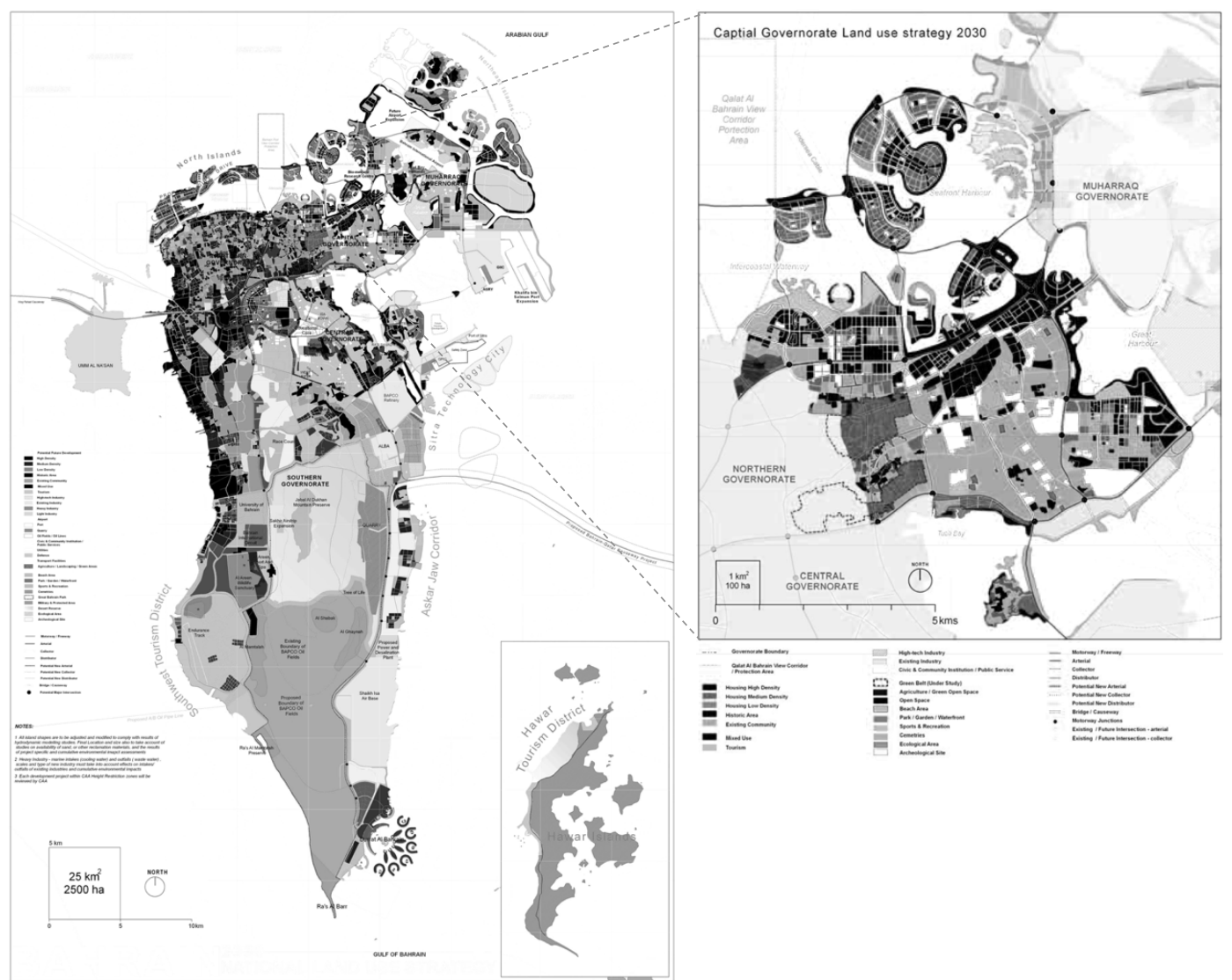

Figure 11: Bahrain (Manama) National Land Use Development Strategy 2030

(Source: MMAUP, 2016). 
Following the critical global crisis in 2008, the Kingdom of Bahrain announces its national vision 2030 as a social strategy rather than an urban planning document facing the current global challenges (Reisz \& Koolhaas, 2010). The aim of the vision is to create economic balance in the country by enabling the middle-class population to be effective participants in the development process. The plan also gives urbanism the greatest share of analysis, as it indicates possible future developments in Manama and defines its urban areas. This comprehensiveness of the planning practice is a requirement for the post-globalization era, creating the acquired balance between endogenous and exogenous systems (Hamouche, 2004).

\section{DISCUSSION AND CONCLUSION}

The urban planning and design practice in the Arabian Gulf region is challenged by globalization and its transformations at different urban scales. However, such challenges are thoughtfully recognized as national priorities in most of the Gulf countries and translated into a series of comprehensive master plans, attempting to introduce efficient management solutions to the infrastructure and urban development based on the pillars of sustainable urbanism. With the assistance of international expertise and foreign investment as efficient forms of global flows, the Arabian Gulf coastal capitals are currently providing dynamic case studies to trace the evolution of cityscapes in the context of globalization.

The efforts towards better urban planning practices are serious, and promising development visions are launching a collaborative framework between the spectra of stakeholders guided by local development authorities, which are responsible for the preparation of planning schemes and implementing grand development projects in the local and regional context. However, the question of urban identity and the conservation of the valuable genesis of urbanism remain unsolved as most of the recent projects in the Gulf capitals are adopting a foreign scheme of design. In order to utilize the theoretical aspirations, careful tactics should respond to the urban challenges in an evolving, participatory way. Ignoring the references of the past or relying on quick, temporary planning practices similar to the trends followed by the Gulf cities during the post-oil eras would result in a poorly managed urbanism.

\section{Contribution to Knowledge}

This research study introduced the evolving realities of urban planning and its practices with response to the active forces of globalization covering the context of the Arabian Gulf region. Results of the theoretical investigation indicate that the planning practice in the Gulf region has been constantly altered and changed responding to the global challenges. New trends of megaprojects, knowledge-transfer planning systems and international consultancy planning are dominating the urban domain, where the knowledge and experience of international expertise are flowing into the local planning practice rather than being diffused or forced by external powers.

Establishing a common ground of urban planning would support the unitary approach of the Gulf region to facilitate their collaboration and to further utilize the powers imbedded within their intergovernmental political union, the GCC. Thus, the practice of urban planning should be challenged by a long-term system that ensure regional collaboration, public participation and the effective integration of the private sector as most of the recent planning practices in the Gulf region are managed by active governance. Accordingly, the future of the urban planning practices is expected to focus on comprehensiveness, master planning in the 
national scale as well as establishing a regional interconnection as a strategic planning vision unifying the whole Arabian Gulf region.

\section{Implications for Practice and Advancement of Research}

The Gulf countries have been witnessing rapid urban transformation and development since the mid-seventies, due to the increased income caused by the oil industry. Further research studies should aim at understanding Gulf dynamics by both international and local consultants, in order to shape adequate and efficient urban planning practices leading the urban development of the Gulf cities. This research study compares the development visions of three Gulf cities and their major aim to evolve as global hubs through an ignited construction boom in the form of mega projects, which are challenged by various historical and contextual aspects. The questions that remain open to further analysis are related to the following concerns: Why do Gulf cities have to grow to hubs for millions? Did globalization enforce the vision of rapid growth? Why does the design of mega projects dominating the urban scene of Gulf cities related to predefined globalized images rather than referential local themes? What is the future of urban planning and design in this prospect?

\section{ACKNOWLEDGEMENTS}

The authors would like to acknowledge the support of Qatar University for creating an environment that encourages scientific research. Also, the authors would like to express their gratitude to the leading planners and architects from the Ministry of Municipality of UAE, Qatar and Bahrain for their collaboration, for participating in the meetings, handling relevant visual data and cardinal documents to the research aims and finally to discuss the conclusive results of this investigation. Finally, the authors thank the anonymous reviewers for their comments, which contributed to significant improvements of this paper. The authors are solely responsible for the statements made herein.

\section{REFERENCES}

Al-Maimani, A., Salama, A. M., \& Fadli, F. (2014). Exploring socio-spatial aspects of traditional souqs: the case of souq Mutrah, Oman. ArchNet-IJAR: International Journal of Architectural Research, 8(1), 50-65. DOI: http://dx.doi.org/10.26687/archnet-ijar.v8i1.356

Agius, D. (2005). Seafaring in the Arabian Gulf and Oman: People of the Dhow (1st ed.). London: Routledge.

Al-Nabi, M. (2012). History of Land use \& Development of Bahrain (1st ed.). Kingdom of Bahrain: Directorate of Government Printing Press - Information Affairs Authority.

Al Nahyan, S. (2000). Political and Social Security in the Arabian Gulf Region and United Arab Emirates. Bratislava: Research Center of the Slovak Foreign Policy Association.

Aoun, O. \& Teller, J. (2016). Planning urban megaprojects in the Gulf: The international consultancy firms in urban planning between global and contingent. Frontiers of Architectural Research, 5(2), 254-264. http://dx.doi.org/10.1016/j.foar.2016.01.003

Barnes, E. L. (1959). The Design Process. Perspecta, 5(1959), 20-22.

Campbell, S. \& Fainstein, S. (2012). Readings in Planning Theory (3rd ed.). Cambridge, USA: Blackwell Publishing Ltd.

Creswell, J. (1994). Research Design, Qualitative and Quantitative Approaches. Thousand Oaks, California: Sage Publications.

Denzin, N. K., \& Lincoln, Y. S. (2005). Handbook of Qualitative Research. London: Sage Publications. 
Elsheshtawy, Y. (2008). The Evolving Arab City. Tradition, Modernity and Urban Development (1st ed.). Oxfordshire: Routledge.

Farewell Arabia. (1968). Special Operations History Foundation.

Furlan, R. (2015). Liveability and Social Capital in West Bay, the New Business Precinct of Doha. Arts and Social Sciences Journal, 6(3), 1-11.

Furlan, R. (2016). Modern and Vernacular Settlements in Doha: An Urban Planning Strategy to Pursue Modernity and Consolidate Cultural identity. Arts and Social Sciences Journal, 7(2), 171-176.

Furlan, R., \& Alattar, D. (2017). Urban Regeneration in Qatar: A Comprehensive Planning Strategy for the Transport Oriented Development (TOD) of AI-Waab. Journal of Urban Regeneration and Renewal, 11(2), 168-193.

Furlan, R., \& Almohannadi, M. (2016). Light Rail Transit and Land Use: An Integrated Planning Strategy for Al-Qassar's TOD in Qatar. Archnet-IJAR: International Journal of Architectural Research, 10(3), 170-192.

Furlan, R., Almohannadi, M., Zaina, S., \& Zaina, S. (2015). Integrated Approach for the Improvement of Human Comfort in the Public Realm: The Case of the Corniche, the Linear Urban Link of Doha. American Journal of Sociological Research, 5(3), 89-100.

Furlan, R., Eissa, B., Awwad, R., \& Awwaad, R. (2015). Neighborhoods and Social Interactions: The Case of Al-Najada Area in Doha. American Journal of Sociological Research, 5(4), 119-133.

Furlan, R., \& El-Ekhteyar, E. (2016). Sense of Community in Gated Communities in Doha: The Case of Al-Ein Compound in Ein Khaled Neighborhood. American Journal of Sociological Research, 6(5), 126-134.

Furlan, R., \& Faggion, L. (2015a). The Development of Vital Precincts in Doha: Urban Regeneration and Socio-Cultural Factors. American Journal of Environmental Engineering, 5(4), 120-129.

Furlan, R., \& Faggion, L. (2015b). The Souq Waqif Heritage Site in Doha: Spatial Form and Livability. American Journal of Environmental Engineering, 5(5), 146-160.

Furlan, R., \& Faggion, L. (2017). Urban Regeneration of GCC Cities: Preserving the Urban Fabric's Cultural Heritage and Social Complexity. Journal of Historical Archaeology \& Anthropological Sciences, 1(1), 1-16.

Furlan, R., \& Mogra, S. (2017). Public Realm at Qatar University Campus: Perception and sustainability of Open Green Spaces. Saudi Journal of Humanities and Social Sciences, 2(1), 80-94.

Furlan, R., N.Eiraibe, \& AL-Malki, A. (2015). Exploration of Sustainable Urban Qualities of Al Saad Area in Doha. American Journal of Sociological Research, 5(4), 101-118.

Furlan, R., Nafi, S., \& Alattar, D. (2015). Urban Built Form of the Souq Waqif in Doha and User's Social Engagement. American Journal of Sociological Research, 5(3), 73-88.

Furlan, R., \& Petruccioli, A. (2016). Affordable Housing for Middle Income Expats in Qatar: Strategies for Implementing Livability and Urban Form. Archnet-IJAR: International Journal of Architectural Research, 10(3), 138-151.

Furlan, R., \& Saeed, M. A. (2017). Strategies for the Enhancement of Users' Social Interactions in Al Mirqab Al Jadeed Street in Doha, State of Qatar. Architecture Research, 7(3), 69-83.

Furlan, R., \& Shurbaji, M. (2017). The Sheraton Park and Users' Human Behaviour: Strategies for Implementation of the Public Realm in Doha. American Journal of Sociological Research, 7(1).

Furlan, R., \& Sipe, N. (2017). Light Rail Transit (LRT) and Transit Villages in Qatar: A PlanningStrategy to Revitalize the Built Environment of Doha. Journal of Urban Regeneration and Renewal, 10(4), 1-20.

Furlan, R., \& Wadi, R. (2017). The Quality of Urban Life (QOUL) of New-Salata Neighborhood in Qatar. American Journal of Sociological Research, 7(1). 
Furlan, R., Zaina, S., \& Zaina, S. (2016). Urban Planning in Qatar: Strategies and Vision for the Development of Transit Villages in Doha. Australian Planner, 53(4), 286-301.

Hamouche, M. (2004). The Changing Morphology of the Gulf Cities in the Age of Globalization: The Case of Bahrain. Habitat International, 28(4), 521-540. http://dx.doi.org/10.1016/j.habitatint.2003.10.006

Khalaf, S. (2006). The evolution of the Gulf city type, oil, and globalization. In J. Fox, N. Sabbah \& M. Al Mutawa, Globalization and the Gulf (1st ed., pp. 244 - 265). London: Routledge.

Khirfan, L. \& Jaffer, Z. (2013). Sustainable Urbanism in Abu Dhabi: Transferring the Vancouver Model. Journal of Urban Affairs, 36(3), 482-502. http://dx.doi.org/10.1111/juaf.12050

Lim, G. (2005). Globalization, spatial allocation of resources and spatial impacts: A conceptual framework. In H. Richardson \& C. Bae, Globalization and Urban Development (1st ed.). Berlin: Springer.

Marshall, C., \& Rossman, G. B. (2006). Designing Qualitative Research. London: Sage Publications.

Ministry of Municipalities Affairs \& Urban Planning MMAUP (2016). Bahrain 2030 The National Plan. Manama: Regional Planning Department.

Murray, M. (2013). Connecting growth and wealth through visionary planning: The case of Abu Dhabi 2030. Planning Theory \& Practice, 14(2), 278-282. http://dx.doi.org/10.1080/14649357.2013.793576

Newman, L. (2007). Basics of Social Research (2 ed.). Boston: Pearson.

Onley, J. (2005). Britain's Informal Empire in the Gulf, 1820 -1971. Journal of Social Affairs, 22(87), 29-45.

Pahl-Weber, E., Seelig, S., Ohlenburg, H., Kuhla von Bergmann, N., \& Schäfer, R. (2013). Urban Challenges and Urban Design: Approaches for Resource-Efficient and Climate-Sensitive Urban Design in the MENA Region. Berlin: Univ.-Verl. der TU.

Ponzini, D. (2011). Large scale development projects and star architecture in the absence of democratic politics: The case of Abu Dhabi, UAE. Cities, 28(3), 251-259. http://dx.doi.org/10.1016/j.cities.2011.02.002

Ragin, C. C. (1994). Constructing Social Research. Thousand Oaks, California: Pine Forge Press.

Ramadan, E. (2015). Sustainable Urbanization in the Arabian Gulf Region: Problems and Challenges. Arts and Social Sciences Journal, 6(2). http://dx.doi.org/10.4172/2151-6200.1000109

Reisz, T. \& Koolhaas, R. (2010). Al Manakh (1st ed.). Amsterdam: Stichting Archis.

Remali, A. M., Salama, A. M., Wiedmann, F., \& Ibrahim, H. G. (2016). A chronological exploration of the evolution of housing typologies in Gulf cities. City Territory and Architecture, 3(14), 1-15.

Richardson, H. \& Bae, C. (2005). Globalization and urban development (1st ed.). Berlin: Springer.

Rizzo, A. (2014). Rapid urban development and national master planning in Arab Gulf countries. Qatar as a case study. Cities, 39, 50-57. http://dx.doi.org/10.1016/j.cities.2014.02.005

Salama, A. M. (2011). Trans-disciplinary knowledge for affordable housing. Open House International, 36(3), 7-15.

Salama, A. M., \& Wiedman, F. (2013 a). Demystifying Doha: On Architecture and Urbanism in an Emerging City. Surrey: Ashgate Publishing Limited.

Salama, A. M., \& Wiedmann, F. (2013 b). The production of urban qualities in the emerging city of Doha: urban space diversity as a case for investigating the 'lived space'. ArchNet-IJAR: International Journal of Architectural Research, 7(2), 160-172.

Salama, A. M., Wiedmann, F., Thierstein, A., \& Al Ghatam, W. (2016). Knowledge economy as an initiator of sustainable urbanism in emerging metropolises: the case of Doha, Qatar. ArchNetIJAR: International Journal of Architectural Research, 10(1), 274-324. DOI: http://dx.doi.org/10.26687/archnet-ijar.v10i1.927 
UN-Habitat, (2012). UN-Habitat Annual Report. UN-HABITAT. Retrieved from http://unhabitat.org/unhabitat-annual-report-2012/

Ward, S. (2012). Re-examining the International Diffusion of Planning. In S. Fainstein \& S. Campbell, Readings in Planning Theory (3rd ed., pp. 479-498). West Sussex, UK: Blackwell Publishing Ltd.

Wiedmann, F., Mirincheva, V., \& Salama, A. M. (2013). Urban reconfiguration and revitalisation: public mega projects in Doha's historic centre. Open House International, 38(4), 27-36.

Wiedmann, F., Salama, A., \& Mirincheva, V. (2014). Sustainable urban qualities in the emerging city of Doha. Journal of Urbanism: International Research On Placemaking and Urban Sustainability, 7(1), 62-84. http://dx.doi.org/10.1080/17549175.2013.870088

Zeisel, J. (1984). Inquiry by Design: Tools for Environment-Behaviour Research. Cambridge: Cambridge University Press.

\section{List of Abbreviations}

$\begin{array}{ll}\text { GCC } & \text { Gulf Cooperation Council } \\ \text { MENA } & \text { Middle East and North Africa } \\ \text { UAE } & \text { United Arab Emirates } \\ \text { UPC } & \text { Abu Dhabi Urban Planning Council } \\ \text { UN } & \text { United Nations } \\ \text { ICFUP } & \text { International Consultancy Firms in the domain of Urban Planning } \\ \text { QNV } & \text { Qatar National Vision } \\ \text { QNDF } & \text { Qatar National Development Framework }\end{array}$

